\title{
Myxobolus leafa sp. nov. (Myxozoa: Bivalbulida) from the gill filament of
} Labeo bata(Hamilton) from Manipur, India

\section{Hindistan (Manipur)'daki Labeo bata Balığının Solungaç Filamentinden Yeni Bir Tür Myxobolus leafasp. nov. (Myxozoa: Bivalbulida)}

\author{
Hemananda Thounaojam¹, Naorem Mohilal1, Probir K. Bandyopadhyay², Amlan Kumar Mitra ${ }^{3}$, \\ Gözde Gürelli
}

'Manipur University, Parasitology Laboratory, Life Sciences Department, Canchipur, India

¿University of Kalyani, Parasitology Laboratory, Department of Zoology, Kalyani, West Bengal, India ${ }^{3}$ Ranaghat College, P.O. Ranaghat, Department of Zoology, District- Nadia, Pin, West Bengal, India ${ }^{4}$ Department of Biology, Faculty of Science and Art, Kastamonu University, Kastamonu, Turkey

\begin{abstract}
Objective: The aim of this study was to investigate the gill filaments of Labeo bata in India parasitologically and to describe the new Myxozoa parasite species, Myxobolus leafa sp. nov., which was determined.

Methods: Fish were collected alive from fish farms from Manipur (India). Sporogonic plasmodia were removed with sterile forceps and observed under phase contrast microscope. For permanent preparations, air dried smears were stained with Giemsa after fixation in acetone free absolute methanol.

Results: Mature spores of the new species appear as leaf-like structures in valvular or frontal view, tapering at both ends. The anterior end of the spore is broader than the posterior end. Spores measure 15.3-11.8 $\mu \mathrm{m}$ (16.91 \pm 1.16$)$ in length and 13.6-15.3 $\mu \mathrm{m}(14.15 \pm 0.67)$ in breadth. Conclusion: The new gill parasite species, Myxobolus leafa sp. nov., was described from fish in India. The prevalence of the parasite was 3.3\% and two stages (cyst and spore) of the parasite existed in its life cycle. (Turkiye Parazitol Derg 2013; 37: 40-3)
\end{abstract}

Key Words: Myxozoa, parasite, fish, Myxobolus leafa sp. nov., India

Received: 01.10.2012 Accepted: 07.12.2012

\section{ÖZET}

Amaç: Bu çalışmanın amacı Hindistan'daki Labeo bata balık türünün solungaç filamentlerini parazitolojik açıdan araştırmak ve tespit edilen yeni Myzoa parazit türünü Myxobolus leafa sp. nov. tanımlamaktır.

Yöntemler: Balıklar Manipur'daki (Hindistan) balık çiftliklerinden canlı olarak elde edilmiştir. Sporogonik plazmodyumlar steril penslerle çıkarılarak faz kontrast mikroskop altında incelenmiştir. Daimi preparasyonlar için, havayla kurumuş yayma preparatlar saf metanolden arındırılmış etanolde tespit edildikten sonra Giemsa'yla boyanmıştır.

Bulgular: Tespit edilen yeni parazit türünün olgun sporları önden bakıldında yaprak benzeridir ve her iki uca doğru daralır. Sporların ön ucu

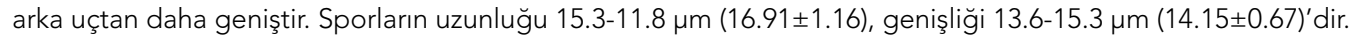

Sonuç: Hindistan'daki balıklardan yeni bir solungaç paraziti Myxobolus leafae sp. nov. tanımlanmıştır. Parazitin yaygınlığı \%3.3'tür ve yaşam döngüsünde 2 safha (kist ve spor) mevcuttur. (Turkiye Parazitol Derg 2013; 37: 40-3)

Anahtar Sözcükler: Myxozoa, parazit, balık, Myxobolus leafa sp. nov., Hindistan

Geliş Tarihi: 01.10 .2012

Kabul Tarihi: 07.12.2012

Address for Correspondence / Yazışma Adresi: Dr. Gözde Gürelli, Department of Biology, Faculty of Science and Art, Kastamonu University, Kastamonu, Turkey Phone: +90 3662801906 E-mail: ggurelli@yahoo.com doi:10.5152/tpd.2013.10 


\section{INTRODUCTION}

Numerous descriptions of myxosporean species of fish have been made from different geographic areas (1, 2). Myxozoa Bütschli, 1882 include more than 1200 valid species commonly found in fish (2, 3). Among them, Myxobolus Bütschli, 1882, with 744 species described, is the largest genus of the family Myxobolidae and has been reported as an important pathogen in freshwater fish (3).

Manipur, located in the Himalayan range, has a rich fish faunal diversity. However, the survival of many indigenous fish species has been hampered with the introduction of many new exotic fish species. This has also given rise to an increase in parasites including myxozoans. Many of these myxosporidans have pathogenic effects on the fish, causing serious damage to various body parts and resulting in heavy economic loss to the fish farmers and also threatening the biodiversity of indigenous fish species.

During a parasitological survey, examinations were conducted on various host fish species, which revealed the presence of a new myxozoan species of the genus Myxobolus from the gill filaments of Labeo bata (Hamilton) collected from a fish farm of Langmeidong, Manipur, India.

\section{METHODS}

Host fish of the genus Labeo bata (Hamilton) were collected alive from fish farms of Langmeidong, brought to the laboratory and examined immediately. Sporogonic plasmodia, when found, were carefully removed with sterile forceps, smeared on clean grease free slides with drops of $0.5 \% \mathrm{NaCl}$ solution, covered with cover slips and sealed with bee wax for examination under the oil immersion lens of the Olympus $\mathrm{CH} 2$ phase contrast microscope. Some of the fresh smears were treated with various concentrations (2-10\%) of $\mathrm{KOH}$ solution for the extrusion of polar filaments. The Indian ink method of was employed for observing the mucous envelope of spores (4). For permanent preparations, air dried smears were stained with Giemsa after fixation in acetone free absolute methanol (5). Measurements (based on twenty fresh spores treated with Lugol's iodine) were done with the aid of a calibrated ocular micrometer. All measurements are presented in $\mu \mathrm{m}$ as mean $\pm \mathrm{SD}$ followed in parentheses by the range.

Drawings were made on fresh or stained material with the aid of a mirror type camera lucida and the Corel Draw 10.0 computer programme.

To describe the morphology of the parasite, several abbreviations have been used, as follows.

\section{RESULTS}

Myxobolus leafa sp. nov. (Figures 1a-j, Tables 1, 2)

Phylum: Myxozoa

Class: Myxosporea

Order: Bivalvulida

Family: Myxobolidae

Genus: Myxobolous

Species: leafa

\section{Diagnosis}

Cyst: Numerous yellowish white, spherical cysts or plasmodia are found attached to the gill filaments of the host, measuring 1.4-1.6 mm in diameter. Cysts contain mostly mature spores. A few developmental stages are also observed.

Spore: Mature spores appear as leaf-like structures in the valvular or frontal view, tapering at both ends. The anterior end of the spore is broader than the posterior end. The spore measures 15.3-11.8 $\mu \mathrm{m} \mathrm{(16.91 \pm 1.168)} \mathrm{in} \mathrm{length} \mathrm{and} \mathrm{13.6-15.3} \mathrm{\mu m}$

Table 1. Measurements of 20 fresh/stained spores of Myxobolus leafa sp. nov.

\begin{tabular}{|l|c|c|c|c|c|}
\hline Characters & Range & Mean & SD & SE & CV (\%) \\
\hline LS & $15.3-18.7$ & 16.91 & 1.168 & 0.261 & 6.907 \\
\hline BS & $13.6-15.3$ & 14.152 & 0.673 & 0.150 & 4.755 \\
\hline LPC & $5.95-8.5$ & 6.67 & 0.724 & 0.162 & 10.854 \\
\hline BPC & $5.1-5.95$ & 5.31 & 0.368 & 0.082 & 6.23 \\
\hline Spore Index \\
\hline LS: BS=1: 0.836 \\
\hline LPC: BPC=1: 0.796 $\quad$ BP $=1: 0.394$ \\
\hline LS: $\quad$ LPC $=1: 0.375$ \\
\hline BS: BPC=1: $0.375:$ breadth of the spore, LPC: length of the polar \\
\hline $\begin{array}{l}\text { LS: length of the spore, BS: } \\
\text { capsule, BPC: breadth of the polar capsule, LPF: length of the polar fila- } \\
\text { ment, DIV: diameter of iodinophilous vacuole }\end{array}$ \\
\hline
\end{tabular}

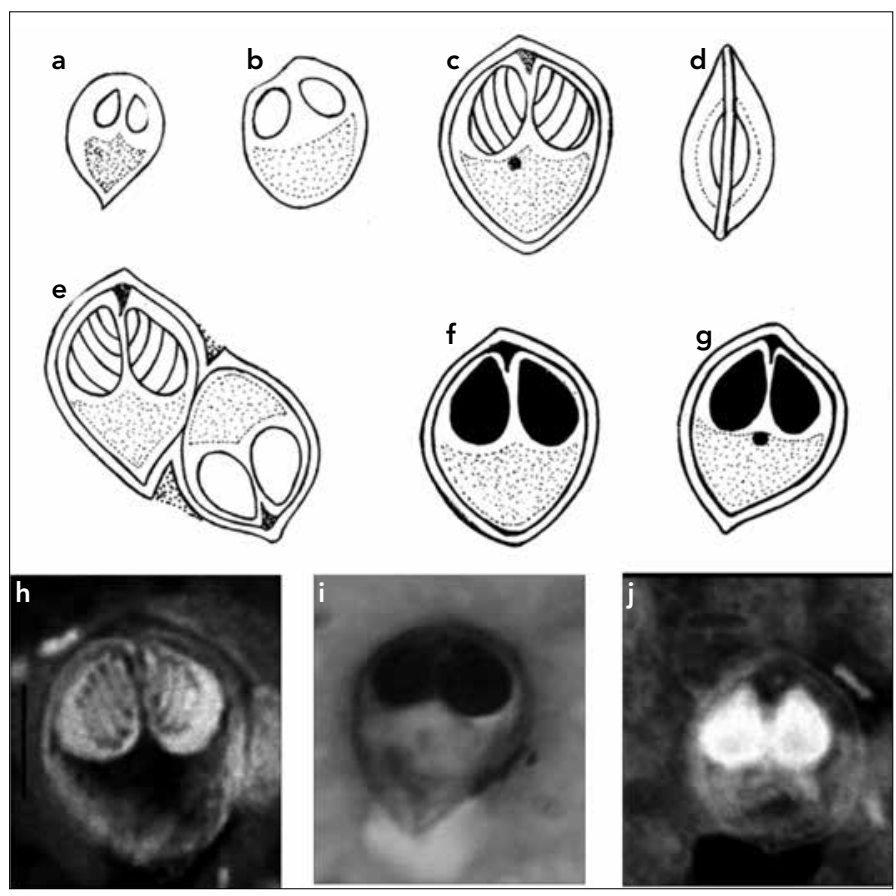

Figure 1. (a-g) Camera lucida drawings of different stages of matured spores of Myxobolus leafasp.nov. (h-j)Photomicrographs of matured fixed spores in valvular view (Giemsa stained) of Myxobolus leafa sp. nov. scale bar - $6.67 \mu \mathrm{m}$. (a, b) Fresh sporedevelopmental stages. (c) Fresh spore in valvular view. (d) Fresh spores in sutural view. (e) Fresh spore in valvular view-Lugol's lodine. $(f, g)$ Fixed spores in valvular view-Giemsa stained 
Table 2. Morphometric comparison of Myxobolus leafa sp. nov. to closely related species

\begin{tabular}{|c|c|c|c|c|c|c|}
\hline Characters & M. drijagini & M. iucundus & M. hendricksoni & M. magnaspherus & M. mokhayeri & $\begin{array}{l}\text { Myxobolus leafa } \\
\text { sp. nov. }\end{array}$ \\
\hline LP & 12.5 & 13 & 13.1 & 18 & $14.4-16.6(15.8)$ & $\begin{array}{c}\text { 15.3-18.7 } \\
(16.19 \pm 1.13)\end{array}$ \\
\hline BS & 9.5 & 10.7 & 12.3 & 20 & $11.6-13.3(12.5)$ & $\begin{array}{c}13.6-15.3 \\
(14.15 \pm 0.67)\end{array}$ \\
\hline LPC & $\begin{array}{c}\text { Unequal } \\
\text { L: 6, S: } 3.35\end{array}$ & 8 & - & 10 & \begin{tabular}{|c|} 
Unequal \\
L: 7.7- $7.9(7.5), \mathrm{S}:$ \\
$5.8-7.5(6.6)$ \\
\end{tabular} & $5.95-8.5,(6.67 \pm 0.72)$ \\
\hline BPC & $\begin{array}{c}\text { Unequal, L: } 3.8 \\
\text { S: } 2.35\end{array}$ & 3.6 & - & 6 & $\begin{array}{l}\text { L: 4.1-4.9 (4.6), } \\
\text { S: 3.3-4.1 (3.6) }\end{array}$ & $5.1-5.95(5.31 \pm 0.36)$ \\
\hline Host & $\begin{array}{c}\text { Hypopthalmichthys } \\
\text { molitrix }\end{array}$ & $\begin{array}{l}\text { Galaxia } \\
\text { maculates }\end{array}$ & $\begin{array}{l}\text { Pimephales } \\
\text { promelas }\end{array}$ & $\begin{array}{l}\text { Lepomis } \\
\text { gibbosus }\end{array}$ & $\begin{array}{l}\text { Capoeta } \\
\text { trutta }\end{array}$ & $\begin{array}{l}\text { Labeo } \\
\text { bata }\end{array}$ \\
\hline $\begin{array}{l}\text { Site of } \\
\text { infection }\end{array}$ & $\begin{array}{l}\text { Subcutaneous } \\
\text { tissue }\end{array}$ & Skin & Brain & Kidney & Fin & Gill \\
\hline Reference & (6) & (7) & (8) & (9) & (10) & Present study \\
\hline
\end{tabular}

$(14.15 \pm 0.67)$ in breadth. On sutural view the spore is pyriform in shape with a distinct, slightly curved sutural line without a ridge or fold. Two shell valves are symmetrical, smooth, thin and uniform with no parietal fold. The posterior part of the spore is surrounded by a mucus envelope.

Two equal polar capsules are oval to pyriform in shape with a broadly pointed anterior end and rounded posterior end. Each polar capsule measures 5.95-8.5 $\mathrm{mm}(6.6 \pm 0.72)$ in length and 5.1$5.95 \mu \mathrm{m}(5.31 \pm 0.36)$ in breadth. Inside the polar capsule, polar filaments coil obliquely forming 4-5 turns. Polar capsules converge slightly at the anterior part. An intercapsular ridge is present as an outgrowth of the inner wall of the spore at the anterior half of the spore cavity. The extracapsular region is occupied by a double crescent shaped sporoplasm. An ,odinophilous vacuole is absent but a tiny sporoplasmic nucleus is present at the upper part of the sporoplasm.

In many cases, the mucus envelope is very prominent while in some spores, the mucus envelope remains in restricted areas at the posterior most part of the spore. In some other cases, the posterior end is prominently pointed-like the tip of a leaf, while in some spores it is bluntly pointed. In most cases the anterior portion is wider than the posterior portion.

\section{Taxonomic Summary:}

Type Host: Labeo bata (Hamilton)

Type Locality: Langmeidong, Thoubal Dist.[240 27/30.47/" N; 93055/15// E]

Site of Infection: Gill

Prevalence: $7 / 210$ (3.3\%)

Type material: Slides containing holotype (MU/P/My) and paratype (MU/P/My ${ }_{\mathrm{a}-\mathrm{d}}$ has been deposited in the collection of Parasitology Section. Life Sciences Department, Manipur University, Canchipur, Imphal, India.)

Number of specimen measured: 30
Etymology: This species was named as per structural resemblance of the parasite to a leaf.

\section{DISCUSSSION}

Due to the presence of two equal pyriform to oval polar capsules with intercapsular appendage, the present myxozoan species is placed under the genus Myxobolus Bütschli, 1882 and group I of Tripathi's grouping of the genus Myxobolus (3). When the present species is compared with other closely related species of the genus Myxobolus, it resembles M. drijagini Akmerov, 1954 (6) reported from the subcutaneous tissue of Hypopthalmichthys molitrix from Amur River, Russia [LP-12.5, BS-9.5, LLPC-6, LSPC-3.35, BLPC-3.8, BSPC-2.35]; M. iucundus Hine, 1977 (7) reported from the skin of Galaxias maculates from New Zealand [LP-13, BS-10.7, LPC-8, BPC3.6]; M. hendricksoni Mitchell et al. (8), reported from the brain of Pimaphales promelas from USA [LP-13.1, BS-12.3]; M. magnaspherus Cone et al. (9), reported from the kidney of Lepomis gibbosus [LP-18, BS-20, LPC-10, BPC-6] and M. mokhayeri Baska et al. (10), reported from the fin of Capoeta trutta [ LS-15.8, BS-12.5, LLPC-7.5, BLPC-4.6, LSPC-6.6, BSPC-3.6]. However, M. drijagini have a smaller spore size, unequal polar capsule and anteriorly more expanded spore than the present species. $M$. iucundus have a smaller spore size, and longer and narrower capsule than the present species. M. hendricksoni also have a smaller spore size than the present species. Moreover, its ovoid or spheroid spore differs from the leaf-like spore of the present species. M. magnaspherus have larger and broader spores than the present species. M. makhayeri have an unequal sized polar capsule whereas the present species have equal sized polar capsules.

\section{CONCLUSION}

Considering all these differences, we propose the Myxobolus species we have obtained from Manipur as new to science and name it as Myxobolus leafa sp. nov.

\section{Conflict of Interest}

No conflict of interest was declared by the authors. 


\section{REFERENCES}

1. Landsberg JH, Lom J. Taxonomy of the genera Myxobolus/ Myxosoma group (Myxobolidae: Myxospodea): current listing of species and revision of synonyms. Syst Parasitol 1991; 18: 165-86. [CrossRef]

2. Lom J, Dyková I. Protozoan parasites of fishes. Development of Aquaculture and Fisheries Science, Elsevier, Amsterdam; 1992.

3. Bütschli O. Myxosporidia. In Bronn's Klass Ordn., des Tierreiches. Protozoa 1882; 1: 590-603.

4. Lom J, Vavrw J. Mucous envelope of spores of the subphylum. Cnidospora (Deflein, 1901). Vist Esl Spol Zool 1963; 27: 4-6.

5. Hemananda T, Mohilal N, Bandyopadhyay PK, Mitra AK. Thelohanellus imphalensis sp. nov. (Myxozoa) infecting gills of a major carp Labeo rohita Hamilton 1822 from Thoubal, Manipur, India. Protistol 2010/11; 6: 280-3.

6. Akhmerov A Kh. K voprosu o "sarannom" kizhuche na kamchatke o porazhenii ryb miksosporidiei I merakh profilaktiki) [Problem of "saran" in silver salmon of Kamchatka (fish disease caused by Myxosporidia and prophylaxis)]. Izv Tikhook Nauchuo-Issled Inst Rybn Khoz I Okeanogr 1954; 41: 347-8.

7. Hine PM. Myxobolus incundus n. sp (Sporozoa: Myxosporidae) parasitic in Galaxias maculates (Jenyns, 1842) in New Zealand. J R Soc N Z 1977; 1: 157-61. [CrossRef]

8. Mitchell LG, Seymour CL, Gamble JM. Light and electron microscopy of Myxobolus hendricksoni sp. nov. (Myxozoa: Myxobolidae) infecting the brain of the fathead minnow, Pimephales promilas Rafinesque. J Fish Dis 1985; 8: 75-89.

9. Cone DK, Anderson RC. Myxosporidian parasites of pumpkinseed (Lepomis gibbosus L.) from Ontario. J Parasitol 1977; 63: 657-66. [CrossRef]

10. Baska F, Masoumian M. Myxocolus molnari sp. n. and M. mokhayeri sp. n. (Myxosporea, Myxozoan) infecting a Mesopotamian fish, Capoeta trutta Heckel, 1843. Acta Protozool 1996; 35: 151-6. 